\title{
Financial Expertise, Authority and Power in the European Football 'Industry'
}

\author{
Herbert F. Moorhouse
}

\begin{abstract}
The paper aims to provoke discussion about two issues. Firstly, how do economic ideas, concepts, theories, principles and information enter into the discourse of the owners and controllers of Europe's most popular sport - football - and into political discussion about the game? It stresses the role management consultants have created for themselves in the new football 'industry'. Secondly, as a specific example of the general concern, the paper considers the role of the Deloitte company in European football. Its publications especially the Annual Reviews of Football Finance - have been very influential and the company has acted as consultants for UEFA on many of the key issues in contemporary football. The paper critically assesses the approach Deloitte has adopted to the commercialisation of football, and explores difficulties in the way it has analysed some of the key issues in European football. It suggests that some countervailing forces need to be created to limit the authority and influence Deloitte currently exercise.
\end{abstract}

\section{Financial expertise and the football industry}

In this paper I aim to provoke discussion about two issues.

Firstly, how do economic ideas, concepts, theories, principles and, indeed, information enter into the discourse of the owners and controllers of Europe's most popular sport - football, and into political discussion about the game? There is, of course, a rapidly growing academic literature about the economics of sport. However, my problem is: does this, and if so, how does this, enter into the minds of the practical men of affairs who run or monitor football clubs, national associations and international bodies? What I want to highlight here is the role of management consultants as intermediaries, as brokers, as interpreters, between the academic realm of ideas and the pressing problems of those who run football. I want to argue that their role is especially significant for two reasons:

1. professional football, though actually quite an old economic activity, has only recently started to be referred to as an 'industry', a term frequently deployed to indicate that an old endeavour has been attributed extra economic significance. In this new European 'industry', business practices and perspectives have not been embraced so wholeheartedly or, at least, so overtly, as they seem to have been in American sport for a century and more. A 'gap' is perceived between 'the values of sport' and the values of business. So, even at the elite level, there is still unease about what is seen as a new incursion of 'commercialism' into a more pristine part of social life, and this requires some group to help 'explain' and bridge this 'gap';

2. much of the control of European football still lies in the hands of national and international associations, headed by administrators rather than entrepreneurs and commercially aware managers, officials geared to applying bureaucratic rules and precedents, rather than seeking the entrepreneurial main chance. Such groups are 
looking for aid and assistance to guide them through all the new problems and opportunities available, as football moves to new cultural and economic positions right across Europe.

This ferment in the fledgling 'industry' has created an opportunity for consultants to step into the structures of European sport as accredited, informed, experts.

Secondly, and as a specific example of my general concern, I want to look at the role of the Deloitte company in European football. For a century and more football was more or less ignored as an economic activity. Now reports from consultants and accountants appear with some frequency, feeding the pages of the financial press as well as the sport sections. These assess the efforts football clubs and sporting associations are making to find new, secure, locations for themselves in a fast-changing world. Especially influential, and not just in England, has been the series of Annual Reviews of Football Finance by the Touche Ross, later Deloitte \& Touche, now Deloitte, company - one of the globe's four large accountancy firms. Starting in 1992, these reports have come to be accepted as the base line for the financial state of the game. They are used by university lecturers to provide academic accounts of the economics of football. They are offered as unimpeachable evidence in cases before the European Court of Justice and submissions to the European Commission. Basically, they are unchallenged as the source of what is going on in the finances of football, about the problems the industry faces, and the possible, practical solutions. The review now sometimes refers to itself as 'the bible of the football industry'.

As I have suggested, this influence reflects the fact that football is still in movement between cultural locations and, despite all the rhetoric, remains essentially a small business activity, and small businesses are often not very financially sophisticated. Then, the European leagues and national associations either do not have the resources to monitor the finances of the game themselves, or do not regard such a task as within their remit. This stands in some contrast with the USA where the organisers of professional leagues do produce a range of statistics and reports which detail the financial situation of the activity and, on occasions, discuss the pertinent problems their sport faces. In addition, the sports ministries and units of various European nations and of the European Commission are rather small bureaux, without the means or the authority to investigate the finances of sports to any depth. So both types of bureaucracies display a tendency to sub-contract the investigation of the health, or otherwise, of sports. Management consultancy firms have quickly stepped into this vacuum, claiming to investigate the progress and problems of contemporary football. They wield influence, have authority and, at one remove, exert considerable power, but their role in the development of European sport is little discussed, or even noticed.

\section{Deloitte and European football}

To begin to rectify this, and to outline some of the key issues, the rest of this paper seeks to critically assess the role of Deloitte and the kind of analyses they offer in their annual reviews, and to discuss what my assessment suggests about the role of accountancy and other professional financial 'experts' within the brave new football world. I seek to show that the series of annual reports and various spin-offs, are marked by two fundamental features:

1. reiteration of the commonsense of the owners and controllers of the football world, without critical analysis, and, at crucial places in their arguments, in the teeth of the actual evidence they present. Deloitte tend to legitimate what football people have always believed - basically they have added a veneer of modernisation to the traditional, received, wisdom of the owners and controllers of the game. Deloitte offer old wine, but in glossy new bottles;

2. concentration on labour market restrictions - of various kinds - as the solution to various financial problems facing football, without commensurate discussion of the efficacy of other policy options which might also deal with these problems. There is, critically, a notable lack of any sustained comparison and contrast with 
the financial arrangements existing in sports in the USA - the more strange an omission, we might think, for a major accountancy and consultancy firm, keen to stress its multinational capabilities on most criteria.

There are many criticisms that can be made of the Deloitte analyses of the financial situation of English and European football, but I will list just six prominent arguments that run right through these reviews, to sketch how their analysis is continually partial, and how advocacy is routinely smuggled into what is presented as dispassionate, expert, analysis. These six arguments are:

1. Deloitte tend to analyse football as a normal business, stressing the significance of, what is a rather untypical status in professional football across Europe, the public limited company, with directors responsible to their shareholders or other investors. The pursuit of profit is taken to be the key objective. This legal form of organisation, in its English form, is taken to be the model, the exemplar, 'the standard bearer' (Deloitte 2007: 2) for what all major European football clubs should aspire to be. Other organisational forms, some much more common in Europe, are mentioned occasionally but never examined as, perhaps, providing more appropriate models for professional football clubs.

2. Deloitte make little reference to the well known point that the fundamental economics of sporting leagues are rather different from most other branches of production. Sporting teams produce a collective, not an individual, product, and this affects the level of free competition it is appropriate to encourage between them if sporting competitive balance is to be maintained. Even when this point is mentioned in the reviews its implications are never traced to any depth. Deloitte finds this a difficult issue to deal with, because, basically it is wedded to promoting the free market as providing the best solutions to the perceived problems of contemporary football.

3. However, while Deloitte self-consciously adopt a rhetoric promoting the benefits of market forces throughout their analyses of the finances of English and European football, they are somewhat inconsistent in their application of the benefits of its rigours. In particular, they constantly stress that players' wages should be constrained by mechanisms other than the free play of market forces. In the Deloitte world view, the market is basically beneficial in its operation everywhere in football except in the determination of players' wages. Deloitte never comment on this intellectual inconsistency in their underlying ideology. Rather football agents are picked out as the villains here, and demonised, as, somehow, better informed, more tightly organised and more ruthless in their negotiations than the owners and managers of even the biggest clubs.

4. Moreover, Deloitte are quite unwilling to trace out the full consequences of the adherence to the free market principles they constantly advocate. Their analysis of European football tends to truncate just as the tensions caused by their constant advocacy start coming into sight. Thus, Deloitte equivocate about issues like the problems of traditionally big clubs based in small media markets, about competitive balance in European football, and find the intervention of billionaire owners like Berlusconi (Milan) and Abramovich (Chelsea) hard to integrate into their analyses. Abramovich's intervention tends to be treated as an 'anomaly', 'exception', 'short term', and even 'the exception that proves the rule' (Deloitte 2004: 43) but quite how this linguistic throwaway is supposed to work, goes totally unexplained. 
5. As I have mentioned, Deloitte tend to focus on labour market restrictions of various kinds as the solution to the financial problems they perceive, and do not discuss other ways in which these problems could be dealt with. They do not detail the ways that other sports, in other countries, are organised so as to deal with such problems. Deloitte never outline the full financial arrangements operating in sport in the USA, but rather warren American systems of sport finance for evidence that labour market restrictions can work, without investigation of the comprehensive nature of all the mechanisms deployed in American sport.

6. As one major aspect of this focus on labour market restrictions, Deloitte have consistently misstated the economic effects of the traditional transfer system, and, from this misreading of the past, misrepresent the current situation, and so promote 'solutions' which cannot deal with most of the real economic and sporting problems facing European football.

I would like to add detail to each of my criticisms, but I do not have the space to do that here. I have dealt with Deloitte's inaccurate analysis of the financial effects of the traditional transfer system in two previous papers, discussing material they produced when acting as consultants for UEFA in both the Bosman case in 1995 and the 'Bosman Mark 2' submission to the European Commission in 2001 (Moorhouse 1999; 2004).

So, in the space available to me, I want to provide more detail on just one of these arguments, my criticism 4 - Deloitte's unwillingness to trace out the full implications of their adherence to the free market as the solution for all of football's problems and the difficulties this leads them to with problems of competitive balance and the intervention of men, rich on a global scale, in European football.

\section{Deloitte: free market football, rich men, and competitive balance}

Deloitte's basic stance on European football is revealed in its 1999 edition. After a suggestion, but only a suggestion, that football is often held to be an unusual kind of business, the analysis continues:

Football's business continues to develop apace - some welcome that and work to channel that dynamic force into business efficiency which creates profitable activity and generates cash for investment in players, stadia, training facilities and complimentary activities to the core football club. Others bemoan the passing of a more egalitarian age when 'market forces' was an irrelevant concept.

Whatever your point of view, the Pandora's box of business structure and market competition in football has been opened and cannot now be closed. Clubs and governing bodies need to choose between embracing that dynamism - even directing and promoting it in certain areas - with attitudes and structures designed for a modern business age and to get the best result for their organisation against that background; or they can react to events, resist the forces (rather than ride them) and end up being swept along in a reluctant and introspective mode. (Deloitte 1999: 5)

And Deloitte go on to try to reconcile what might be thought to be irreconcilable:

The figures suggest that most of the smaller countries would still struggle to compete financially with the clubs from the larger European countries. Demographics are not things that can be easily changed. Many national leagues are struggling to maintain competitive balance at a local level...In some leagues competitive balance has never really existed .... 
Polarisation of 'football power' has always existed, it is not a recent phenomenon caused by economic development. We believe that properly structured commercial development enhances competitive balance. We also believe, to that end, in football harnessing the market's power - not in any Authority interfering in it, or with it. (Deloitte 1999: 63-4)

So adherence to the market will, somehow, bring competitive balance. For one thing Deloitte is definitely against is the idea of any attempt, by any state body, by any regulator, to interfere with 'the market's power' except, to repeat, as regards players wages. At one time, it tended to advocate the adoption of 'gentlemen's agreements' between clubs to create caps on the amount of total revenue that could be spent on wages. Indeed, when in 2002 the G14 group of elite clubs announced the adoption of just such a salary cap for the clubs in its organisation (which very little has been heard of subsequently) Deloitte were named as the official monitors of this arrangement, just as the Deloitte reviews continued to praise the 'realism' of the initiative.

In fact, the issue of competitive balance has not featured much in Deloitte's literature on football, but, in the early $21^{\text {st }}$ century, the consultant has had to shed its reluctance to confront the issue of competitive balance within European national leagues and in panEuropean competition. So, in the 2004 edition, to those worried about signs of an increasing predictability in European football, Deloitte offer a few ad hoc and mainly irrelevant counter examples (an argumentative device typical of these reviews) and add reassuringly:

That is the beauty of the game - football remains a game of eleven versus eleven and nothing is certain. This makes it a tough business to manage - plans will go awry but it is the same magic that draws in the fans and generates the value. That the past few months have shown football still has that magic is of great benefit to the sport in business terms. (Deloitte 2004: 5).

Here Deloitte appeal to 'magic' but systematic discussion of the economic forces driving contemporary developments in the game and what the impetus of free market football will inevitably lead to, goes undiscussed. What Deloitte do, and, again, fairly typical of their mode of arguing, is to align these growing concerns about competitive balance with an issue that is preoccupying the bureaucratic controllers of football. Once UEFA and Deloitte - both in its reviews and in its material contained in UEFA's submission to the European Court and the Commission - used to claim that the traditional transfer system was the bedrock of football's financial arrangements, its key redistributive mechanism, cascading money 'down' from rich to poor, but in recent years it is the collective selling of TV rights, by UEFA and national associations, that is declared to have that role (UEFA 2005: 10,13,20,23). So Deloitte argue:

The bigger risk to football's finances is from ill-judged interference in the broadcast market for football from regulators. (Deloitte 2004: 4)

And:

A particular area of concern to football is any further regulatory attempt to artificially prevent exclusivity by, for example, forcing individual selling by clubs. This is a recipe for disaster - not just for broadcasters and football clubs but also for fans and consumers .......We are pleased regulators now apparently recognise collective selling as the glue that holds football together. (Deloitte 2004: 4 and 11)

Later Deloitte inform readers that the football authorities have apparently been successful in:

... convincing the European Commission of the specific dynamics of sport and in particular collective selling and its role in providing, among other things, solidarity between rich and poor clubs, and competitive balance within a football competition. (Deloitte 2004: 21) 
In contrast to the 'mayhem' the selling of rights by individual clubs has caused in some countries, football must:

... champion the wide array of benefits that collective selling brings, including solidarity between clubs, redistribution mechanisms to maintain competitive balance, and most importantly providing coherent delivery of a product to consumers and fans. (Deloitte 2004: 21)

The next year Deloitte reiterate the message:

Collectively, the challenge for clubs, leagues and governing bodies over the coming years will be to continue to ensure competitive balance and uncertainty of outcome in domestic and European competition over the long term..... The collective selling of media rights has a fundamental role to play in that. This promotes solidarity and helps keep the Premiership closer to the National Football League in the USA (an oftquoted model of competitive balance and economic strength) than the polarised and predictable football leagues in some other European markets. (Deloitte 2005: 3)

It would take a long time to unpack all the half-truths, misleading analogies and empirical inaccuracies contained in this paragraph, but I hope I have begun to make clear how Deloitte now tends to align the issue of competitive balance in European football directly with the mechanism of collective selling, and not even the system of the redistribution of those revenues obtained by collective selling. This is a very important distinction which few of the voices arguing about this issue make, though, thankfully, the European Commission's White Paper on Sport does stress this point (European Commission 2007a: 17; 2007b: 53-56). In the UEFA and Deloitte ideology, there has been a swift and unexplained change of main argument here, away from the 'indispensability' of the traditional transfer system to the vital role that collective selling is claimed to play in dealing with the key problems of contemporary football.

I have to sound a warning that what UEFA (aided by Deloitte) argued about the functioning of the transfer system was empirically inaccurate, and their current stress on the importance of maintaining collective selling is similarly misplaced. Later I will show that Deloitte consistently overstates the significance of this particular revenue stream, even for the five major leagues in Europe, let alone for the far more numerous leagues in small/less rich nations, and suggest that it cannot allow that competitive imbalance may be coming, in part at least, from the interventions of extremely rich individuals who control a weight of resources that can 'distort the market' regardless of the, actually quite minor, income redistributions achieved via collective selling.

Deloitte tend to deal with the issue of competitive balance not via an analysis of the likely outcomes for European football of relying on market forces, but through more enigmatic phrases and a consistent refusal to consider the issue head-on. For example, just a few pages on from the last quote I used, the new TV deal for French football is hailed for being 'more meritocratic and less egalitarian' (Deloitte 2005: 14) which seems to be the precise opposite of what it had been arguing earlier. But then, consistency is not a fundamental characteristic of the Deloitte analyses of the finances of European football. Deloitte tends to argue that there are competitions within leagues that keep the public interested regardless of overall domination by a few clubs and that:

... any team can beat any other team on their day. This uncertainty of outcome maintains interest throughout the season. (Deloitte 2006: 2).

It is notable that maintaining competitive balance has not figured on the 'Strategic Challenges' table for the football industry which has been a feature of recent reviews.

Another aspect of modern football which Deloitte find difficult to deal with is the ownership of teams by men, rich on a world scale, whose wealth easily outstrips the normal finances of even the biggest clubs. It is not easy to fit them into the neat business model for European 
football which Deloitte continually advocates. Deloitte argues both that there is nothing new in business men being attracted to football but urge that, at best, such a commitment should be directed to allow a club to:

... attain a genuine business model to sustain a healthy life for the club at that level, without significant ongoing benefaction. (Deloitte 2005: 56)

Deloitte grapple with these issues directly in 2005 in a special section - "What has Roman ever done for us?" - about the Russian owner of Chelsea who had:

... transformed the face of football....less than two years later, this hastily arranged transaction is one of the most significant changes of ownership in the history of sport. This is by no means the first sizeable personal investment in a football club, but the speed and scale of it towers above anything previously witnessed. (Deloitte 2005: 42)

Deloitte go onto argue that the rest of the English Premiership:

has decided to let them get on with it. Previously, competitive urges have always pushed clubs up to and beyond their financial boundaries. Perhaps the scale of Chelsea's spending is simply in another league and all other clubs recognise that? (Deloitte 2005: 42)

Deloitte also welcomes signs that Chelsea had announced plans to 'stand on its own two feet' and run the club 'properly'. This is all very well, but the Deloitte reviews consistently argue that there is a positive link between expenditure on players' wages and sporting success. It is possible to buy championships and cups, and Deloitte currently estimate Abramovich's financial input into Chelsea at about $£ 475$ million. Deloitte find this issue - at base a question of why very wealthy men might want to own European football clubs other than for a business opportunity - hard to deal with because it cuts across their moral view of the way football should be organised in the contemporary world. Yet questions of the acquisition of status and power through football, rather than a straightforward search for profits, are tangled around the controllers of many clubs all across Europe. Such benefits may well lead onto other profitable opportunities in indirect ways, but Deloitte's whole conceptual scheme is not subtle enough to really grasp the range of personal motivations in play in the modern game.

\section{The Independent European Sport Review, the Belet Report, and the White Paper}

Similar problems of analysis also occur in the Independent European Sport Review of 2006. This is not altogether surprising since Gerry Boon, who was in charge of the Deloitte sports business group and the annual review for its first 13 years, was chairman of the economics sub-committee which helped produce the Independent Review. This curious document funded by UEFA - stems from the UK Presidency of the European Commission in 2005, which, through the sports ministers of the nations that host the richest Big 5 leagues in European football (England, Spain, Italy, France and Germany), initiated a review that, while purporting to be a review of sport, actually concentrates on European football. It is designed to put pressure on the European authorities, especially the Commission and the Court of Justice, to recognise what is claimed to be the particular place of sport in Europe and to create a special legal status for sporting bodies, especially UEFA.

It seeks to do this by claiming that:

The European Sports Model has delivered success and earned respect around the world as a system based on social inclusion, financial solidarity and true sporting values. (Arnaut 2006: 13) 
However, it argues that this success is threatened by an irreversible trend towards the commercialisation of sport and, at the same time, by the expansion of the European Union to 25 member states. Actually this second factor is scarcely mentioned, and the focus is all on how the European sports 'pyramid' requires strengthening so as to serve the needs of European sport in years to come.

There are many criticisms that could be made of this document. The European Sport Model, for instance, is a highly idealised version of the organisation of sport across the continent, lacking both historical and cultural specificity. Many organisations quickly pointed out that what applies in football does not apply in their sports. And what the European Model is routinely favourably compared to - the American Model of Sport - is similarly stereotyped. But what I want to concentrate on is the kind of economic arguments deployed. In general there is a massive overstatement of the 'solidarity' operating in European football, a misapplication of issues of 'competitive balance', both done with the intent to sanctify and solidify the status of UEFA.

Like the Deloitte reviews, this report is determined to link problems of competitive balance with the central selling of media rights, so:

... collective selling and the mutualisation of the resulting revenue is a fundamental aspect of sporting organisation and an essential component in the solidarity structure inherent to European sport. (Arnaut 2006: 50)

And:

Central (or collective) selling is fundamental to protect the financial solidarity model of European football....an essential means to help promote competitive balance and finance the future development of football. (Arnaut 2006: 51)

Like the Deloitte reviews there are three key reasons why this concentration on the central selling of media rights in relation to competitive balance is quite misplaced:

- it tends to imply that a significant amount of redistribution does take place within existing systems of collective selling in club competitions - which is untrue;

- it tends to imply that media rights are the main source of income in most European club competitions - which is untrue;

- it tends to imply that other streams of revenue cannot be redistributed, when they have been in the past in many European countries and are routinely in contemporary American sports.

The Champions League in 2005/06 generated revenues of 610 million euros. Seventy two percent of this total - 437 million euros - went to the 32 clubs in the group stages, clubs mainly from the biggest leagues and biggest media markets. Of this, the four English clubs involved earned a total of 145 million euros. In some contrast, just 60 million euros went to other stakeholders in European football as 'solidarity payments', with the 36 European leagues which had no representative in the final 32 clubs, receiving just 8 million euros or 1.3 per cent of total revenue (Deloitte 2007: 18). Strangely the Arnaut report does not contain this kind of detail, even though in Annex 3 which is devoted to the 'solidarity and redistribution system in European football' the report claims:

... the UEFA Champions League (UCL) is based on a system of central or collective selling that is fundamental to protect the financial solidarity model of European football (...)In the context of the UCL, central marketing and the resultant redistribution of revenues serves a crucial role. (Arnaut 2006: 155)

In short, even in the major club competition that UEFA directly controls, redistribution mechanisms are perfunctory and have little or no effect in disturbing market generated 
inequalities between clubs and between leagues (Moorhouse 2004). In other club competitions around Europe, traditional mechanisms of redistribution have tended to truncate, rather than develop, in recent decades (Moorhouse 2000).

Then, even in the biggest leagues, income from media rights makes up less than 50 per cent of the total on average (Deloitte 2007: 14). Concentrating on this revenue stream as the solution to growing inequality in football is dealing, at best, with only half the cause of the problem. Moreover, across Europe in leagues outside the Big Five, income from media rights forms a much smaller part of total revenues. In the Netherlands, for example, the most financially successful league outside the Big Five, income from TV rights formed just 20 per cent of total revenues in 2005-06. Given this, then a concentration on collective selling and any revenue redistribution from this source, simply ignores the problems of the vast majority of Europe's leagues. When European MP. Ivo Belet, both a member of the political subcommittee of the Independent European Sport Review and the rapporteur of the European Parliament's Report on the Future of Professional Football in Europe (basically a totally supportive companion piece to the Independent Review) commented about the White Paper on Sport:

As regards the sale of TV rights, the Parliament asks for a much clearer signal. The financial race that increases the gap between the large, rich clubs and smaller, not so wealthy ones needs to stop. This can only be done by opting for the collective selling of TV rights. (Belet 2007)

Belet simply revealed that he had little understanding of the significant patterns of inequality within leagues and between leagues in Europe. Deloitte's latest report estimates that clubs in the top divisions in the Big 5 leagues take 53 per cent of all the income for football in Europe. The top divisions of the other 47 countries in UEFA's 'family' take just 14 per cent of the total. Such a pattern, with obvious consequences for sporting success in pan-European competition, will not be altered by interventions that concentrate on collective selling within the top divisions of various nations.

Deloitte and UEFA are trying to forge a link between collective selling and competitive balance on the basis of a few selective statistics, and amnesia about the real situation in most of European and pan-European football. But, however often the mantra is repeated, the facts reveal that collective selling is not, of itself, any kind of solution to problems of competitive balance. Only comprehensive and systematic revenue sharing arrangements - a crucial feature of the American sports model - will achieve that.

\section{Conclusions}

There are many points that could be drawn out of my outline of issues around financial expertise in European football. It has implications, for example, for the so-called 'European model of sport', for consideration of Deloitte's position raises rather neglected issues about who actually wields power, authority and influence within European football.

Then Deloitte and UEFA consistently overstate the degree of 'solidarity' that occurs in the European football 'family', and the strength of the 'links' down the 'pyramid' to the amateur level of sport. Through this they have, reasonably successfully, mobilised bias against certain other actors in the football 'industry', groups like G14 and players agents, especially among the political class in the big nations and in the European Parliament. Their mis-statements of the nature of the problems in European football and the simplistic solutions they offer tend to be eagerly swallowed by gullible politicians, all too keen to get a popular headline, but too busy to do the research necessary to really appreciate the true extent of the problems. A realisation that UEFA and Deloitte are essentially lobbyists, rather than a poorly treated and much misunderstood organising body and a dispassionate financial 'expert', needs to be accepted before a sensible future can be devised for football across Europe. 
A lot gets written today about teams and players developing themselves as brands, and how consumers are attracted to brands because of the guaranteed quality of service they are thought to provide. But 'the football industry', the European Parliament, the Commission and the European Court of Justice are, themselves, as consumers, easily impressed by brand names. And Deloitte is an internationally recognised brand. Its expertise is largely unchallenged, the brand name alone tends to convince. Because of the lack of counterweights - especially independent or state bodies which could create and analyse statistical information, and produce reports in an open and transparent way a feature of the much maligned American model of sport - Deloitte has achieved a powerful niche role as the financial expert for European football and sport more widely. De facto it has almost become the 'the independent regulator' that many believe European football requires. Great dangers lie in this. Countervailing institutions need to be created and supported so as to maintain a balance in discussion about the best future for European football.

\section{References}

Arnaut J.L. (2006). Independent European Sport Review (October, final version).

Belet I. (2007). 'EU White Paper on Sports: Too Weak a Signal', press release from EPP-ED group in European Parliament, 11 July.

Deloitte (1992-2007). Annual Review of Football Finance. Manchester: Deloitte.

European Commission (2007a). White Paper on Sport (COM 2007, 391 final version).

European Commission (2007b). The EU and Sport: Background and Context, accompanying document to the white paper, (SEC 2007 935).

European Parliament, Committee on Culture and Education (2007). Report on the Future of Professional Football in Europe (A6-0036/2007, final version)

Moorhouse H.F. (1999). 'Football Post-Bosman: The Real Issues', in C. Jeanrenaud and S.Kesenne (eds) Competition Policy in Professional Sports: Europe after the Bosman Case. Antwerp: Standaard editions.

Moorhouse H.F. (2000). 'The Redistribution of Income in European Professional Football: Past, Present and Future', Reflets et Perspectives, 39 (2-3).

Moorhouse H.F. (2004). 'Economic Inequalities Within and Between Professional Soccer Leagues in Europe: Sporting Consequences and Policy Options', in R. Fort and J. Fizel (eds) International Sports Economics Comparisons. London: Praeger.

UEFA (1995). Update to UEFA Member Associations Concerning the Bosman Case. Nyon, Switzerland: UEFA.

UEFA (2000). The Football Transfer System: Report of the Task Force Sub-Committee on Economic Matters. Nyon, Switzerland: UEFA.

UEFA (2005). Vision Europe. Nyon, Switzerland: UEFA. 